\title{
APPLICATION OF PROFITABILITY CONCEPT: A CASE IN THE PLASTIC RECYCLING INDUSTRY
}

\author{
S.A. Oke ${ }^{1}$, O.E. Charles-Owaba ${ }^{2}$ and I.O. Popoola ${ }^{3}$ \\ ${ }^{1,3}$ Department of Mechanical Engineering \\ University of Lagos, Nigeria \\ sa_oke@yahoo.com \\ ${ }^{2}$ Department of Industrial and Production Engineering \\ University of Ibadan, Nigeria
}

\begin{abstract}
In this article the principles of industrial engineering are applied to maximize the profitability of the recycling industry. A case in the plastic recycling industry is presented to demonstrate the practical application of the financial calculation functions developed in the paper. In particular, the profitability maximization concept for the plastic recycling industry was examined, based on the theory of demand and supply. By estimating the profit realizable on regular as well as high product demand, part of the objective of the paper was achieved. Inventory principles were further applied to determine optimum inventory levels.
\end{abstract}

\section{OPSOMMING}

Die beginsels van bedryfsingenieurswese word in die artikel toegepas om die maksimisering van winsgewendheid by herwinbaarheidsvraagstukke te bewerkstellig. 'n Voorbeeld wat voorkom by die herwinbaarheid van plastiek word voorgehou om te toon hoedat finansiële modellering aangewend kan word. Voorraadhouding onder toestande van stabiele en toenemende vraag word behandel en in besonderheid ondersoek. 


\section{INTRODUCTION}

In recent times, recycling and recycling practices have become increasingly important owing to the pressures experienced by industries worldwide [6]. For example, a strong indication of the "end-of-life directives" endorsed by the European Union is that, if resources are not recycled, a period may come when very limited resources are available to humanity. Consequently, we may need to suffer for the shortage of these important resources. With the numerous supports for investment in recycling technology and operation, many industrialists are considering the possible expansion of existing structures and processes in order to maximize profits [27, 28]. With the benefits of saving costs, protecting the environment from pollution, and making maximum use of available resources, international agencies and other stakeholders are also investing in projects that will enhance the promotion of environmental cleanliness through recycling.

Over the last decade, efforts have been made to formalize the economic and financial calculations relating to recycling - and especially plastic recycling, which is the main focus of this paper - through life-cycle approaches [2, 12, 16]. Furthermore, the economics of recycling are constantly debated [11, 20,21]. The contribution of this paper is to add value to the field of industrial engineering in general through the application of calculation procedures or mathematical methodologies in the plastic recycling industry. The paper presents a clear case study demonstrating the use of the mathematical functions. An overview of selected research articles relating to recycling of different types of materials, including plastics, is presented.

\section{RELEVANT LITERATURE}

The research methodology for selecting and assessing the papers reviewed here is based on a SWOT-type analysis of the different approaches, which indicated the need for a new financial model. The SWOT-type analysis also reveals the different approaches that are considered for inclusion in the development of such a new model. The literature reviewed here relates to the current theoretical modelling of recycling in the fields of "designing for recycling" and "life-cycle costing" $[3,8,9$, 22].

Recycling has numerous advantages. Waste from recycling is usually channelled into refuelling the recycling process or sold to other industries as a useful source of fuel for operations. Therefore, with recycling, new ideas and products are created. Such products tend to be more suitable for application than those created from raw materials. Unfortunately, recycled materials may not be ideal for the purpose of materials made from raw materials. The process of recycling is characterised by a lack of technical know-how, skilled and trained personnel, and facilities. Another threat to recycling is that it is impossible to recycle some materials. Also, a lot of time, dedication, and extensive research are needed to determine how best to recycle material. Another threat is that there are few experts in the field of recycling in underdeveloped countries. Where they exist, the technology may not be technically sound. In Table 1 below, we present the SWOT-type analysis to reveal the strengths, weaknesses, opportunities, and threats of the available approaches in the literature on recycling. 


\begin{tabular}{|c|c|c|c|c|c|}
\hline S/No. & $\begin{array}{l}\text { Approach } \\
\text { /Author }\end{array}$ & Strengths & Weaknesses & Opportunities & Threats \\
\hline 1. & $\begin{array}{l}\text { Goosey } \\
\text { and } \\
\text { Kellner } \\
{[7]}\end{array}$ & $\begin{array}{l}\text { Work highlights new legislation to } \\
\text { encourage the recycling of end-of- } \\
\text { life electronics. } \\
\text { Focuses attention on large } \\
\text { quantities of printed circuit boards } \\
\text { (PCBs) being consigned to landfill } \\
\text { by electronics manufacturing } \\
\text { firms. } \\
\text { New methodologies for dealing } \\
\text { with end-of-life circuit boards are } \\
\text { identified as a priority issue. } \\
\text { Reports on study carried out to } \\
\text { identify the technologies and } \\
\text { processes that can be used to } \\
\text { recycle materials from end of life } \\
\text { PCBs. }\end{array}$ & $\begin{array}{l}\text { Work does not reflect } \\
\text { profitability elements } \\
\text { Only a small part (15\%) of } \\
\text { total PCB scrap currently } \\
\text { generated is subject to any } \\
\text { form of recycling. A major } \\
\text { part is consigned to landfill. }\end{array}$ & $\begin{array}{l}\text { Approach could also be extended } \\
\text { to other materials such as } \\
\text { electromechanical systems, } \\
\text { computer accessories, } \\
\text { automobile components, etc. } \\
\text { It is an environmental pollution } \\
\text { reduction strategy. As part of } \\
\text { municipal waste that is properly } \\
\text { disposed of, it helps to reduce } \\
\text { public waste that would } \\
\text { constitute a health hazard } \\
\text { Achieving increase in the level } \\
\text { of recycled end-of-life } \\
\text { electronics products, with focus } \\
\text { on attaining complete recycling } \\
\text { of all electronics products }\end{array}$ & $\begin{array}{l}\text { Low awareness and non- } \\
\text { challant attitude from } \\
\text { members of the public } \\
\text { The people and } \\
\text { government's willingness } \\
\text { to implement work, but } \\
\text { then discarding it } \\
\text { midway. }\end{array}$ \\
\hline 2. & $\begin{array}{l}\text { Ross and } \\
\text { Evans } \\
{[24]}\end{array}$ & $\begin{array}{l}\text { The result of study that } \\
\text { demonstrates that recycle and reuse } \\
\text { strategies for plastic-based } \\
\text { products can yield significant } \\
\text { environmental benefits } \\
\text { Utilises a highly valuable approach } \\
\text { to the analysis of recycling cost } \\
\text { with the use of the life cycle cost } \\
\text { concept }\end{array}$ & $\begin{array}{l}\text { No discussion about the } \\
\text { relationship of life cycle to } \\
\text { profitability is offered. }\end{array}$ & - & - \\
\hline
\end{tabular}

Table 1: Strength Weakness Opportunity and Threat (SWOT) analysis of the different approaches 


\begin{tabular}{|c|c|c|c|c|c|}
\hline S/No. & $\begin{array}{l}\text { Approach } \\
\text { /Author }\end{array}$ & Strengths & Weaknesses & Opportunities & Threats \\
\hline 3. & $\begin{array}{l}\text { Smith } \\
\text { et al. } \\
\text { [25] }\end{array}$ & $\begin{array}{l}\text { It surveys several schemes that } \\
\text { collect plastic bottles for recycling } \\
\text { in the UK. } \\
\text { An Environment Act imposes a } \\
\text { legal requirement for plastic } \\
\text { packaging to be recycled. } \\
\text { A national target of } 15 \% \text { recycling } \\
\text { of plastic packaging waste by } 2001 \\
\text { was implemented. }\end{array}$ & $\begin{array}{l}\text { This survey project did not } \\
\text { investigate modelling. } \\
\text { Further assistance was } \\
\text { required in order to meet the } \\
\text { national target. } \\
\text { The profitability of financial } \\
\text { functions relating to plastic } \\
\text { recycling was not identified by } \\
\text { the authors. }\end{array}$ & $\begin{array}{l}\text { It highlights various recycling } \\
\text { schemes in the UK with respect } \\
\text { to their distribution, efficiencies, } \\
\text { and types. Other areas such as } \\
\text { effectiveness, acceptance, and } \\
\text { control could be further } \\
\text { examined. }\end{array}$ & $\begin{array}{l}\text { The people's adherence to } \\
\text { or apathy towards the } \\
\text { Environment Act will go } \\
\text { a long way to determining } \\
\text { its success or failure. }\end{array}$ \\
\hline 4. & $\begin{array}{l}\text { Treloar } \\
\text { et al. } \\
\text { [27] }\end{array}$ & $\begin{array}{l}\text { Focuses on waste minimization } \\
\text { strategies and use of recycled } \\
\text { materials for the construction of } \\
\text { residential buildings. } \\
\text { Embodied energy is a useful } \\
\text { indicator of resource value. } \\
\text { This paper thoroughly identifies } \\
\text { the various types of waste that } \\
\text { were generated from the } \\
\text { construction of a typical standard } \\
\text { house. } \\
\text { Study discovers that amount of } \\
\text { wasted material was less than that } \\
\text { found previously by others in cases } \\
\text { in capital cities. } \\
\text { Innovative waste management } \\
\text { strategies aimed at reducing the } \\
\text { resource requirement of the } \\
\text { construction process. }\end{array}$ & $\begin{array}{l}\text { Cost and embodied energy } \\
\text { savings from using materials } \\
\text { with recycled content were } \\
\text { potentially more beneficial in } \\
\text { terms of embodied energy and } \\
\text { resource depletion than waste } \\
\text { minimization strategies. }\end{array}$ & - & - \\
\hline
\end{tabular}

Table 1 (cont'd): Strength Weakness Opportunity and Threat (SWOT) analysis of the different approaches 


\begin{tabular}{|c|c|c|c|c|c|}
\hline S/No. & $\begin{array}{l}\text { Approach } \\
\text { /Author }\end{array}$ & Strengths & Weaknesses & Opportunities & Threats \\
\hline 5. & $\begin{array}{l}\text { Lee } \\
\text { et al. } \\
{[14]}\end{array}$ & $\begin{array}{l}\text { Recycling is a major source of employment and } \\
\text { research opportunities. } \\
\text { Critical analysis of recycling potential of plastic } \\
\text { waste generated by healthcare facilities through the } \\
\text { evaluation of disposal costs, plastic contents, } \\
\text { components, sources, and amount of medical plastic } \\
\text { waste. } \\
\text { It cites some methods to increase or improve the } \\
\text { recycling of medical plastic waste. } \\
\text { It predicts recycling becoming a major sector in } \\
\text { many economies of the world in the years to come; } \\
\text { making a significant impact on both the environment } \\
\text { and human lives. }\end{array}$ & $\begin{array}{l}\text { No consideration is given to } \\
\text { profitability measures of plastic } \\
\text { recycling system. }\end{array}$ & - & - \\
\hline 6. & $\begin{array}{l}\text { Gobin and } \\
\text { Mano [6] }\end{array}$ & $\begin{array}{l}\text { It possesses the potential to become a commercially } \\
\text { viable recycling process. } \\
\text { This method exposes the recycling process as } \\
\text { important in helping in research for suitable } \\
\text { materials, better and more efficient industrial } \\
\text { processes. } \\
\text { Some recycled materials, such as pillard clays, } \\
\text { offered about the same performance as fresh } \\
\text { samples. }\end{array}$ & $\begin{array}{l}\text { High initial cost involved in setting up } \\
\text { recycling plants. } \\
\text { A lot of research must be carried out to } \\
\text { discover the best recycling modes for } \\
\text { material. }\end{array}$ & - & - \\
\hline
\end{tabular}

Table 1 (cont'd): Strength Weakness Opportunity and Threat (SWOT) analysis of the different approaches 


\begin{tabular}{|c|c|c|c|c|c|}
\hline S/No. & $\begin{array}{l}\text { Approach/ } \\
\text { Author }\end{array}$ & Strengths & Weaknesses & Opportunities & Threats \\
\hline 7. & $\begin{array}{l}\text { Price and } \\
\text { Donald } \\
\text { [19] }\end{array}$ & $\begin{array}{l}\text { Discourse is based on real-life cases of 3M life cycle } \\
\text { management implementation. } \\
\text { Its significance pushes the responsibility of } \\
\text { manufacturess beyond the factory environment to } \\
\text { include product use by customers and disposal of } \\
\text { products. } \\
\text { It highlights environmental, health and safety (EHS) } \\
\text { opportunities. } \\
\text { Identifies competitive market advantages resulting } \\
\text { from superior performance. } \\
\text { It manages a product's EHS risks as well as } \\
\text { resources and energy use throughout a product's life } \\
\text { cycle. } \\
\text { It is a means of reducing environmental pollution. } \\
\text { The recycled products are modified, thus having a } \\
\text { wider range of use than the original product. } \\
\text { Reduces overall expenditure in production, and it is } \\
\text { highly profitable. } \\
\text { Process consists of simple steps to follow. }\end{array}$ & $\begin{array}{l}\text { No relation to the profitability concept in } \\
\text { plastic recycling. } \\
\text { Recycling may not reduce overall } \\
\text { degradation of environment if other forms } \\
\text { of pollution are not controlled. }\end{array}$ & $\begin{array}{l}\text { The } \\
\text { modification } \\
\text { of recycled } \\
\text { products } \\
\text { explores the } \\
\text { opportunity to } \\
\text { locate some } \\
\text { products that } \\
\text { will meet some } \\
\text { demands. }\end{array}$ & $\begin{array}{l}\text { Some products are } \\
\text { such that it is } \\
\text { difficult for the } \\
\text { manufacturer to } \\
\text { exercise control } \\
\text { over their use by the } \\
\text { consumer - e.g. } \\
\text { firearms, drugs, etc. }\end{array}$ \\
\hline 8. & $\begin{array}{l}\text { Lawson } \\
\text { et al. } \\
\text { [13] }\end{array}$ & $\begin{array}{l}\text { Detailed analysis of construction and demolition } \\
\text { waste (C \& D waste) generated annually to the tune } \\
\text { of } 53.5 \mathrm{Mt} \text {; of which } 51 \% \text { went to landfill, } 40 \% \text { was } \\
\text { used for land reclamation and only } 9 \% \text { was crushed } \\
\text { for future use or directly recovered. } \\
\text { Improved sampling procedures and } \\
\text { recommendations for risk assessment for the reuse of } \\
\text { C and D waste were being prepared. } \\
\text { Attitudes or preferences shifting towards disposal on } \\
\text { site. }\end{array}$ & $\begin{array}{l}\text { C \& D waste may be contaminated } \\
\text { through spillage from industrial processes } \\
\text { or contact with contaminated land. } \\
\text { No guidelines on how to classify C \& D } \\
\text { waste as contaminated, nor on risk } \\
\text { management for contaminated C \& D } \\
\text { waste. } \\
\text { New taxes made disposal of C \& D waste } \\
\text { to landfill uneconomical. } \\
\text { Low grade 'land-modeling' recycling is } \\
\text { increasing. }\end{array}$ & $\begin{array}{l}\text { To prepare } \\
\text { guidelines on } \\
\text { C \& D waste } \\
\text { classification. }\end{array}$ & - \\
\hline
\end{tabular}

Table 1(cont'd): Strength Weakness Opportunity and Threat (SWOT) analysis of the different approaches 


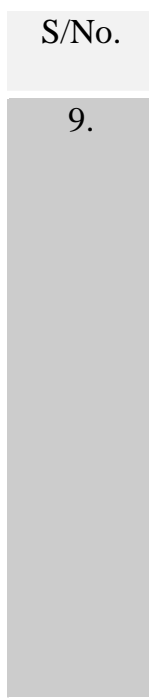

10.
Approach/

Author

Romualdo

el al.

[23]
Strengths

Investigates recycling of granite industry waste from the northeast region of Brazil; samples of wastes of several granites companies located there were collected.

Waste could be used in substitution of conventional raw materials in ceramic formulations in proportions up to $50 \%$. This is important in saving traditional raw material in the region.

Aims at the possibility of using sawing granite waste as alternative ceramic raw materials for the production of bricks and roof tiles.

Samples of sawing granite wastes were submitted for technological tests revealing waste having size,

distribution and composition similar to conventional non-plastic ceramic raw materials.

Investigates the development of integrated design for disassembly and recycling in concurrent engineering. Notes previous environment revolution addressing waste reduction at the source.

Cites previous measures aimed at cleaning up

hazardous waste from contaminated sites and natural resources.

Proffers effective methods, such as the design of products that promote disassembly, re-use and recycling.

Encourages the design of environmentally friendly products by applying axiomatic design to develop integrated, acceptable, and best designs.

\section{Weaknesses}

They discover that solid wastes are one of the worst problems in the world

today, owing to increase in volume and environmental contamination.

Annually, high disposal costs are

incurred worldwide in environmental protection efforts.
Opportunities Threats

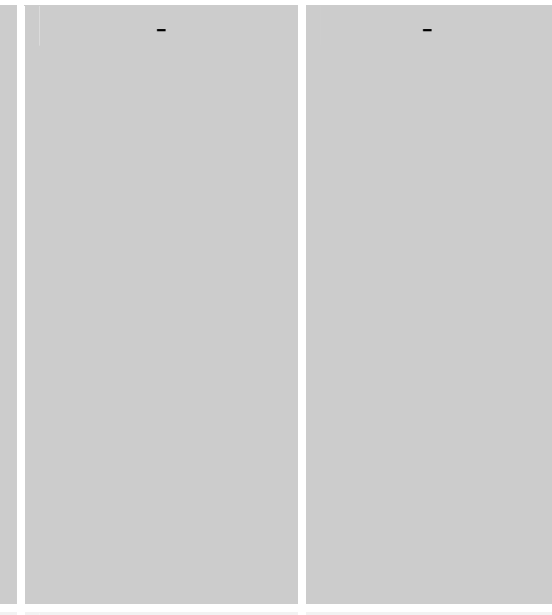

Table 1(cont'd): Strength Weakness Opportunity and Threat (SWOT) analysis of the different approaches 


\section{REGULAR DEMAND}

From the basic knowledge acquired from economics, the flow rate Q, which is a measure of the quantity of recycled product, is a function of the price at which it was sold, i.e. $\mathrm{QR}=\mathrm{f}(\mathrm{Sp})$. When the quantity recycled increases, the overall selling price may increase, but the selling price per unit will reduce. This can be graphically represented as shown below (Figure 1).

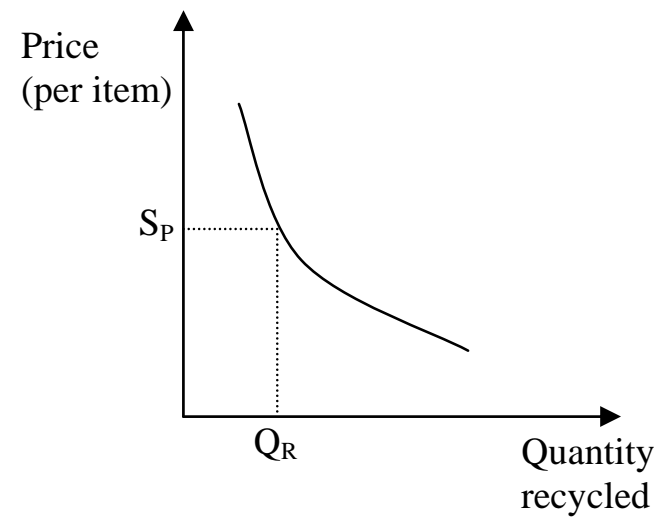

\section{Figure 1: Recycled quantity and time (regular demand)}

$\mathrm{S}_{\mathrm{p}}=$ selling price per item at a particular instance

$\mathrm{Q}_{\mathrm{R}}=$ quantity recycled at that instance

The main reason for establishing a business is to make a profit, so as to increase the business capital and provide income to the owner of the business. The greater the quantity recycled for sale, the higher the profit. Profit is the excess of price over cost price, i.e.:

Profit, $\mathrm{X}=$ Selling Price (SP) - Cost Price (CP)

But, $\quad$ Selling Price (SP) = Selling Price per unit (Sp) x Quantity Recycled $\left(\mathrm{Q}_{\mathrm{R}}\right)$

Cost Price $(\mathrm{CP})=$ Cost Price per unit $(\mathrm{Cp}) \times$ Quantity Recycled $\left(\mathrm{Q}_{\mathrm{R}}\right)$

Therefore, $\quad$ Profit, $X=\left(S p \times Q_{R}\right)-\left(C p \times Q_{R}\right)=(S p-C p) Q_{R}$

\subsection{Definition of Terms}

(i) $\mathrm{S}_{\mathrm{p}}$ is the selling price per item of the quantity of plastic wastes recycled. The selling price could vary depending on the cost price at the time and the choice of the recycler.

(ii) $\mathrm{Cp}$ is the cost price per item of the quantity of plastic wastes recycled. This would be based on a peripheral computation to be carried out by the recycler. Consideration should be given to all expenses incurred directly during the recycling process. This includes collection of plastic wastes, size reduction 
(cutting and shredding), separation or sorting, cleaning and drying, etc. Other expenses that are indirectly incurred include salaries and wages, rent, depreciation of machines and equipment, sundry expenses, etc.

(iii) $\mathrm{Q}_{\mathrm{R}}$ is the quantity of plastic waste recycled. The quantity recycled can be determined by the application of the model which helps to assign values to the recycled quantities - i.e.

Also, let

$\mathrm{D}=$ screw diameter;

$\mathrm{H}=$ channel depth in the metering zone;

$\mathrm{B}=$ flow width

$\mathrm{W}=$ channel width parallel to the screw axis;

$\theta=$ Helix angle of the screw

$\mathrm{N}=$ screw speed in revolutions per second (rps);

$\mathrm{V}=$ linear velocity

$\mathrm{Q}_{\mathrm{R}}=\frac{\text { volume flow rate }\left(\mathrm{Q} \text { in } \mathrm{m}^{3} / \mathrm{s}\right) \times \text { period }(\mathrm{T} \text { in sec })}{\text { volume }\left(\mathrm{V} \text { in } \mathrm{m}^{3} / \text { item }\right)}$

$=\left[\frac{\pi \mathrm{DhWNCos}{ }^{2} \theta}{2}-\frac{\mathrm{h}^{3} \mathrm{WPCos} \theta}{12 \mathrm{~L} \mu \mathrm{a}}\right] \frac{\mathrm{T}}{\mathrm{V}}$ item

where $\mathrm{T}=$ period between the beginning of recycling and the expected completion time.

$\mathrm{V}=$ volume that makes each item of the recycled product.

Therefore, $\quad$ Profit, $\mathrm{X}=\left[(\mathrm{Sp}-\mathrm{Cp}) \frac{\pi \mathrm{DhWNCos}{ }^{2} \theta}{2}-\frac{\mathrm{h}^{3} \mathrm{WPCos} \theta}{12 \mathrm{~L} \mu \mathrm{a}}\right] \frac{\mathrm{T}}{\mathrm{V}}$

\section{UPSURGE IN DEMAND}

In the recycling industry, it is usually at certain periods that there is a sudden upsurge in demand from customers. This upsurge could be weekly, monthly or even yearly. Upsurge is a specific problem in the recycling industry [7, 15]. For instance, in the case of a weekly demand cycle, it is likely that demand would rise on Fridays for various parties.

Upsurge in the industry could happen in two ways:

(i) Immediate increase in demand (order)

(ii) Future (unforeseen) increase in demand (order) 


\section{Immediate increase in demand}

If a customer usually demands $\mathrm{Q}_{\mathrm{R}}$ items, the company probably recycles just that quantity. But with an increase in demand - say, $\mathrm{Q}_{\mathrm{R} 2}$ items - the company must meet it in order not to lose customers or future sales.

The proposed model would help suppliers to meet such situations. With slight adjustments in some of the parameters, the change in quantity recycled could be expressed in Figure 2.

Considering the profit before $\left(\mathrm{X}_{1}\right)$ and after $\left(\mathrm{X}_{2}\right)$ increase:

Profit before $\left(\mathrm{X}_{1}\right): \quad \mathrm{X}_{1}=\mathrm{S}_{\mathrm{P} 1}-\mathrm{C}_{\mathrm{P} 1}=\left(\mathrm{S}_{\mathrm{P} 1}-\mathrm{C}_{\mathrm{P} 1}\right) \mathrm{Q}_{\mathrm{R} 1}$

where $\mathrm{Q}_{\mathrm{R} 1}=\frac{\mathrm{Q}_{1} \times \mathrm{T}}{\mathrm{V}}$

$\mathrm{x}_{1}=\left(\mathrm{S}_{\mathrm{P} 1}-\mathrm{C}_{\mathrm{P} 1}\right) \times \frac{\mathrm{Q} 1 \mathrm{~T}}{\mathrm{v}}=\left[\left(\mathrm{S}_{\mathrm{P} 1}-\mathrm{C}_{\mathrm{P} 1}\right) \frac{\pi \mathrm{D}_{1} \mathrm{~h}_{1} \mathrm{~W}_{1} \mathrm{~N}_{1} \operatorname{Cos}^{2} \theta_{1}}{2}-\frac{\mathrm{h}_{1}{ }^{3} \mathrm{~W}_{1} \mathrm{P}_{1} \operatorname{Cos} \theta_{1}}{12 \mathrm{~L}_{1} \mu \mathrm{a}_{1}}\right] \frac{\mathrm{T}}{\mathrm{V}}$

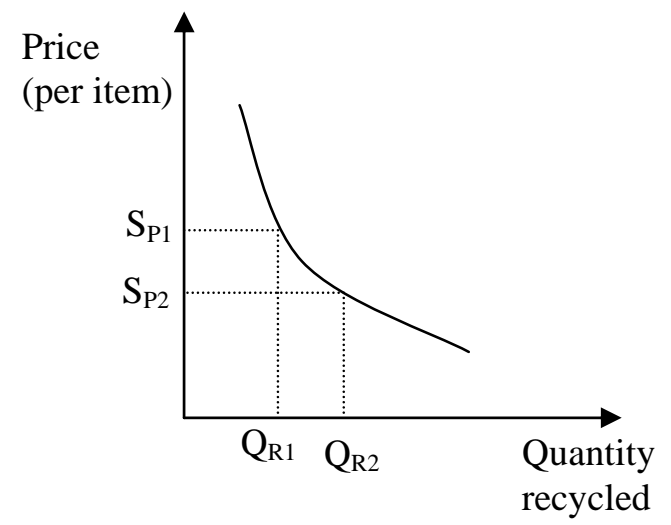

Figure 2: Recycled quantity and time (upsurge conditions)

\subsection{Definition of terms}

(a) (i) All terms are the same as those described under regular demand. Only the subscript 1 indicates the original value of all the parameters, before change.

(ii) Profit after $\left(\mathrm{X}_{2}\right)$

$$
\begin{gathered}
\mathrm{X}_{2}=\mathrm{SP}_{2}-\mathrm{CP}_{2}=\left(\mathrm{S}_{\mathrm{P} 2}-\mathrm{C}_{\mathrm{P} 2}\right) \mathrm{Q}_{\mathrm{R} 2}= \\
{\left[\left(\mathrm{S}_{\mathrm{P} 2}-\mathrm{C}_{\mathrm{P} 2}\right) \frac{\pi \mathrm{D}_{2} \mathrm{~h}_{2} \mathrm{~W}_{2} \mathrm{~N}_{2} \operatorname{Cos}^{2} \theta_{2}}{2}-\frac{\mathrm{h}_{2}{ }^{3} \mathrm{~W}_{2} \mathrm{P}_{2} \operatorname{Cos} \theta_{2}}{12 \mathrm{~L}_{2} \mu \mathrm{a}_{2}}\right] \frac{\mathrm{T}}{\mathrm{V}}}
\end{gathered}
$$

(b) (i) $\mathrm{S}_{\mathrm{P} 2}$ is the selling price per item of the increased quantity $\left(\mathrm{Q}_{\mathrm{R} 2}\right)$. In most cases, this price is slightly lower than the original selling price per item $\left(\mathrm{S}_{\mathrm{P} 1}\right)$. 
It is usually a percentage of $S_{\mathrm{P} 1}-$ i.e. $S_{\mathrm{P} 2}=a S_{\mathrm{P} 1}$. The percentage "a" depends on the recycler.

(ii) $\mathrm{C}_{\mathrm{P} 2}$ is the cost price per item of the increased quantity $\left(\mathrm{Q}_{\mathrm{R} 2}\right)$. As explained earlier, computation of the cost price per item depends on the expenses incurred both directly and indirectly. Direct expenses on collection, reduction, sorting, etc. would definitely increase as long as the quantity recycled increases. However, indirect expenses such as salaries, wages, rent, etc. might not necessarily change. Similarly, $\mathrm{S}_{\mathrm{P} 2}$, the cost price per item, would be slightly lower than the original cost price per item. It is also a percentage of $C_{P 1}-$ i.e. $C_{P 2}=b C_{P P}$. It should be noted that the cost incurred due to changing any of the parameters falls under direct expenses.

(iii) One or more of the eight parameters that make up $\mathrm{Q}_{\mathrm{R} 2}$ could be adjusted, depending on the recycler's choice, policy, and strategy in meeting the increased quantity. This implies that some of these parameters would not change, since changing all would increase the cost. This would not favour the recycler's quest for profit.

(iv) Period (T) and volume (V) would not change. The period and volume remain the same for either the original quantity or the increased quantity.

(c) The increase in profit as a result of meeting the increased quantity QR2 can be measured by:

$$
\begin{aligned}
\mathrm{X}_{0}=\mathrm{X}_{2}-\mathrm{X}_{1}= & {\left[\left(\mathrm{S}_{\mathrm{P} 2}-\mathrm{C}_{\mathrm{P} 2}\right)\left(\frac{\pi \mathrm{D}_{2} \mathrm{~h}_{2} \mathrm{~W}_{2} \mathrm{~N}_{2} \operatorname{Cos}^{2} \theta_{2}}{2}-\frac{\mathrm{h}_{2}{ }^{3} \mathrm{~W}_{2} \mathrm{P}_{2} \operatorname{Cos} \theta_{2}}{12 \mathrm{~L}_{2} \mu \mathrm{a}_{2}}\right)\right] } \\
& -\left[\left(\mathrm{S}_{\mathrm{P} 1}-\mathrm{C}_{\mathrm{P} 1}\right)\left(\frac{\pi \mathrm{D}_{1} \mathrm{~h}_{1} \mathrm{~W}_{1} \mathrm{~N}_{1} \operatorname{Cos}^{2} \theta_{1}}{2}-\frac{\mathrm{h}_{1}^{3} \mathrm{~W}_{1} \mathrm{P}_{1} \operatorname{Cos} \theta_{1}}{12 \mathrm{~L}_{1} \mu \mathrm{a}_{1}}\right)\right] \frac{\mathrm{T}}{\mathrm{V}}
\end{aligned}
$$

Simplifying this expression, we have $\mathrm{X}_{0}=\left[\left(\mathrm{S}_{\mathrm{P} 2}-\mathrm{C}_{\mathrm{P} 2}\right) \mathrm{Q}_{2}-\left(\mathrm{S}_{\mathrm{P} 1}-\mathrm{C}_{\mathrm{P} 1}\right) \mathrm{Q}_{1}\right] \frac{\mathrm{T}}{\mathrm{V}}$

\section{Unforeseen increase in demand}

In this case, the increase in demand lies in the future, but the company presumes that it will occur at some time. Therefore the company recycles a greater quantity than is actually needed at that time. The effect of this on the increase in profit $\left(\mathrm{X}_{0}\right)$ is seen in the need to keep the excess recycled products in store. The cost of keeping the excess in store includes:

(a) Storage charges - i.e. rent, lighting, insurance, and security.

(b) Interest on capital investment on the stored products.

\subsection{Storage cost analysis}

The cost of holding items in storage and of interest on the money invested in the items is directly proportional to the quantity of the items $\mathrm{Q}_{\mathrm{RS}}$. This quantity $\mathrm{Q}_{\mathrm{RS}}$ is 
the difference between the actual recycled product $\mathrm{Q}_{\mathrm{R} 2}$ and the present demand $\mathrm{Q}_{\mathrm{R} 1}-$ i.e.:

$\mathrm{Q}_{\mathrm{RS}}=\mathrm{Q}_{\mathrm{R} 2}-\mathrm{Q}_{\mathrm{R} 1}=\left(\mathrm{Q}_{2}-\mathrm{Q}_{1}\right) \frac{\mathrm{T}}{\mathrm{V}}$

Assuming that the average quantity of items in store is $\frac{Q_{R S}}{2}$, and that $H$ represents the holding cost per item per period $(\mathrm{t})$, then Holding Cost $(\mathrm{HC})=\frac{\mathrm{HQ}_{\mathrm{RS}}}{2}$.

Also, let $\mathrm{CP}=$ cost price (investment) $=\mathrm{C}_{\mathrm{P} 2}-\mathrm{C}_{\mathrm{P} 1}$, and $\tau=$ interest rate of money invested in $\mathrm{Q}_{\mathrm{RS}}$.

Therefore, Interest Charge $(\mathrm{IC})=\left(\mathrm{C}_{\mathrm{p}}\right) \times(\mathrm{i}) \times \frac{\mathrm{Q}_{\mathrm{RS}}}{2}=\frac{\mathrm{iC}_{\mathrm{P}} \mathrm{Q}_{\mathrm{RS}}}{2}$

Total Storage Cost, $\mathrm{T}_{\mathrm{SC}}=\mathrm{H}_{\mathrm{C}}+\mathrm{I}_{\mathrm{C}}=\frac{\mathrm{HQ}_{\mathrm{RS}}}{2}+\frac{\mathrm{iC}_{\mathrm{P}} \mathrm{Q}_{\mathrm{RS}}}{2}=\left[\mathrm{H}+\mathrm{iC}_{\mathrm{P}}\right] \frac{\mathrm{Q}_{\mathrm{RS}}}{2}$

but $\quad \mathrm{H}=\frac{\mathrm{h}}{\mathrm{t}}$

where $\mathrm{h}=$ holding cost per item

$\mathrm{t}=$ time the excess quantity $\mathrm{Q}_{\mathrm{RS}}$ spends in the store.

Therefore $\quad \mathrm{T}_{\mathrm{SC}}=\left(\frac{\mathrm{h}}{\mathrm{t}}+\mathrm{iC}_{\mathrm{P}}\right) \frac{\mathrm{Q}_{\mathrm{RS}}}{2}$

\section{Maximum profitable period ( $t$ ) of storage}

It is possible for the quantity $\mathrm{QRS}_{\mathrm{RS}}$ to be stored and sold when there is an upsurge in demand, but for the company still to run at a loss. It is important to note that the increase in profit $\mathrm{X}_{0}$, must be more than the total storage cost $\mathrm{T}_{\mathrm{SC}}$ for profit - i.e. $\mathrm{X}_{0}$ $>\mathrm{T}_{\mathrm{SC}}$. For easy assessment in the recycling industry, it is best stated in terms of the maximum time that the company should keep the items in store. To obtain the maximum time that the items can be stored, it is best to equate the increase in profit, $\mathrm{X}_{0}$, to the total storage cost, $\mathrm{T}_{\mathrm{SC}}$.

Therefore,

$$
\begin{aligned}
& {\left[\left(\mathrm{S}_{\mathrm{P} 2}-\mathrm{C}_{\mathrm{P} 2}\right) \mathrm{Q}_{2}-\left(\mathrm{S}_{\mathrm{P} 1}-\mathrm{C}_{\mathrm{P} 1}\right) \mathrm{Q}_{1}\right] \frac{\mathrm{T}}{\mathrm{v}}=\left(\frac{\mathrm{h}}{\mathrm{t}}+\mathrm{iC}_{\mathrm{P}}\right) \frac{\mathrm{Q}_{\mathrm{RS}}}{2}} \\
& \frac{\mathrm{h}}{\mathrm{t}}+\mathrm{iC}_{\mathrm{P}}=\frac{2 \mathrm{~T}}{\mathrm{VQ}_{\mathrm{RS}}}\left[\left(\mathrm{S}_{\mathrm{P} 2}-\mathrm{C}_{\mathrm{P} 2}\right) \mathrm{Q}_{2}-\left(\mathrm{S}_{\mathrm{P} 1}-\mathrm{C}_{\mathrm{P} 1}\right) \mathrm{Q}_{1}\right]
\end{aligned}
$$




$$
\begin{aligned}
\frac{\mathrm{h}}{\mathrm{t}} & =\frac{2 \mathrm{~T}}{\mathrm{VQ}_{\mathrm{RS}}}\left[\left(\mathrm{S}_{\mathrm{P} 2}-\mathrm{C}_{\mathrm{P} 2}\right) \mathrm{Q}_{2}-\left(\mathrm{S}_{\mathrm{P} 1}-\mathrm{C}_{\mathrm{P} 1}\right) \mathrm{Q}_{1}\right]-\mathrm{iC}_{\mathrm{P}} \\
\frac{\mathrm{h}}{\mathrm{t}} & =\frac{2 T\left[\left(\mathrm{~S}_{\mathrm{P} 2}-\mathrm{C}_{\mathrm{P} 2}\right) \mathrm{Q}_{2}-\left(\mathrm{S}_{\mathrm{P} 1}-\mathrm{C}_{\mathrm{P} 1}\right) \mathrm{Q}_{1}\right]}{\mathrm{VQ}_{\mathrm{RS}}}-\mathrm{iC}_{\mathrm{P}} \\
\mathrm{t} & =\mathrm{h}\left[\frac{2 \mathrm{~T}\left[\left(\mathrm{~S}_{\mathrm{P} 2}-\mathrm{C}_{\mathrm{P} 2}\right) \mathrm{Q}_{2}-\left(\mathrm{S}_{\mathrm{P} 1}-\mathrm{C}_{\mathrm{P} 1}\right) \mathrm{Q}_{1}\right]}{\mathrm{VQ}_{\mathrm{RS}}}-\mathrm{iC}_{\mathrm{P}}\right]^{-1}
\end{aligned}
$$

but $\mathrm{H}=\frac{\mathrm{h}}{\mathrm{t}}$

where $\mathrm{h}=$ cost of holding in storage

$\mathrm{t}=$ time the excess quantity $\mathrm{Q}_{\mathrm{RS}}$ spends in store per year.

Since the storage time might not be measured in years, it is reasonable and practicable to reduce it to weeks.

1 year $=52$ weeks; $\mathrm{t}$ years $=\frac{52}{1} \mathrm{xt}$ weeks $=52 \mathrm{t}$ weeks

$\therefore 52 \mathrm{t}=\mathrm{h}\left[\frac{2 \mathrm{~T}\left[\left(\mathrm{~S}_{\mathrm{P} 2}-\mathrm{C}_{\mathrm{P} 2}\right) \mathrm{Q}_{2}-\left(\mathrm{S}_{\mathrm{P} 1}-\mathrm{C}_{\mathrm{P} 1}\right) \mathrm{Q}_{1}\right]}{\mathrm{VQ}_{\mathrm{RS}}}-\mathrm{iC}_{\mathrm{P}}\right]^{-1}$

$\mathrm{t}=\frac{\mathrm{h}}{52}\left[\frac{2 \mathrm{~T}\left[\left(\mathrm{~S}_{\mathrm{P} 2}-\mathrm{C}_{\mathrm{P} 2}\right) \mathrm{Q}_{2}-\left(\mathrm{S}_{\mathrm{P} 1}-\mathrm{C}_{\mathrm{P} 1}\right) \mathrm{Q}_{1}\right]}{\mathrm{VQ}_{\mathrm{RS}}}-\mathrm{iC}_{\mathrm{P}}\right]^{-1}$

$\mathrm{t}($ in wks $)=\frac{\mathrm{h}}{52}\left[\frac{2 \mathrm{~T}\left[\left(\mathrm{~S}_{\mathrm{P} 2}-\mathrm{C}_{\mathrm{P} 2}\right) \mathrm{Q}_{2}-\left(\mathrm{S}_{\mathrm{P} 1}-\mathrm{C}_{\mathrm{P} 1}\right) \mathrm{Q}_{1}\right]}{\mathrm{VQ}_{\mathrm{RS}}}-\mathrm{iC}_{\mathrm{P}}\right]^{-1}$

\section{CASE STUDY}

In order to explain the practical application of the model developed in this work, the case of a plastic recycling plant situated in a major city in southern Nigeria is used as an example. The process consists of two main sub-processes: pre-recycling, and the main recycling.

The pre-recycling processes are: (i) collection; (ii) size reduction; (iii) separation or sorting; and (iv) cleaning and drying. The major polymer recycling process is extrusion. Extrusion is a polymer conversion operation. It is employed to recycle and homogenize the plastic, and produce a material that is easy to work with to produce new products. In this process, a solid thermoplastic material is melted, forced through a die of the desired cross-section, and cooled. The devices used to carry out extrusion are called extruders.

Although there are many types of extruders, the most common is the single-screw extruder. This consists of a screw in a metal cylinder or barrel. The barrel is 
surrounded by electric heater bands and fans. The screw is connected through a thrust bearing and gearing to a drive motor that rotates the screw in the barrel. A conical hopper is connected to the feed throat, a hole in the barrel near the drive end of the screw. The opposite end of the barrel is fully open and exposes the tip of the screw. A die is connected to the "open" end of the extruder. During extrusion, solid plastic in the form of pellets is fed from the hopper, through the feed throat of the extruder, and into the extruder barrel. The pellets fall on to the rotating screw and are packed in the first section of the screw (called the feed zone). The packed pellets are melted as they travel through the middle section (called the transition zone) of the screw, and the melt is mixed in the final section (called the metering zone). Although the heater bands and cooling fans maintain the barrel at a set temperature, conduction from the barrel walls provides only $30 \%$ to $40 \%$ of the energy required to melt the resin. The remaining energy is generated from the mechanical motion of the screw; this is called viscous dissipation.

Pressure generated in the metering zone of the extruder screw forces the melt through the breaker plate and die. The breaker plate provides a seal between the extruder and die, and converts the rotational motion of the melt (in the extruder) to linear motion (for the die). The breaker plate also holds a screen pack that filters the melt. The die forms the melt into the desired shape. Ancillary equipment is used to cool the melt and pull the cooled material away from the die.

Three types of flow exist in a single-screw extruder. The rotating screw pushes material along the walls of the stationary barrel (cylinder), which creates drag flow (QD). This drag flow provides the forward conveying action of the extruder, and in the absence of a die, is effectively the only flow present. The addition of a die restricts the open discharge at the end of an extruder and produces a large pressure gradient along the extruder. Since the pressure is greatest just before the die, this head creates the other two flows, pressure flow $\left(\mathrm{Q}_{\mathrm{P}}\right)$ and leakage flow $\left(\mathrm{Q}_{\mathrm{L}}\right)$. In pressure flow, the head pressure forces the melt to rotate in the channels of the extruder screw. Leakage flow occurs when the head pressure forces melt back over the flights of the screw. Since these are both counter-motions of the melt, pressure and leakage flow are often lumped together as 'back flow'. During normal extruder operation, drag flow conveys the polymer along the barrel walls, whereas pressure flow forces the material near the screw back towards the hopper. A simple mathematical modelling of extrusion can be made by assuming the following conditions:

- $\quad$ the extruder is at steady state

- $\quad$ the melt is Newtonian (viscosity does not change with changes in shear rate)

- $\quad$ the melt is isothermal (at a constant temperature) and

- $\quad$ the metering zone makes the only contribution to output.

Thus the net output, Q, of the extruder can be expressed as:

$\mathrm{Q}=\mathrm{Q}_{\mathrm{D}}-\mathrm{Q}_{\mathrm{P}}-\mathrm{Q}_{\mathrm{L}}$ 
From our assumptions, the metering zone of the screw is expected to contain almost $100 \%$ melt and be at an almost constant temperature. Consequently, if an estimation of the output from this zone is possible, then the output from the whole extruder can be estimated, considering the geometry of the flow in the metering zone of an extruder screw.

\section{DISCUSSION OF RESULTS}

The major aim of the recycling profitability measure is to assist recyclers in quantifying the profit they could make in a particular recycling production. It gives them room to evaluate the increase in profit. Furthermore, an expression was derived to assist recyclers in determining how long recycled products could be allowed to remain in storage before the excess profit would be lost. All of these were achieved by applying various principles from economics and operations research - for example, the theory of demand and supply, and the principles of inventory. With the recycler's ability to assign numerical values to the various parameters in the equation, the possibility of determining the increased profit and the maximum time in store is very high.

\section{CONCLUSIONS}

In this work, some industrial engineering tools were applied to the plastic recycling industry in order to improve organizational performance by improving profitability. In particular, a case study demonstrated the applicability of the presented financial calculation model. The case revealed a situation in which an upsurge in product demand affected the profitability of the organization. Having demonstrated the feasibility of applying the financial model in a real life situation, a wide array of opportunities for future development of the financial calculation functions was presented.

Every establishment aims at making profit for the purpose of expansion. With this in mind, this financial model has been examined to see how it could be useful in estimating the profit made on a particular quantity being recycled within a particular period. Since the model has the benefit of assisting the industry to increase the quantity being produced within the same period, it was considered necessary to examine the additional profit that the industry could make by meeting an upsurge in demand. A mathematical expression to assist in this was developed. This expression is useful when the increase in demand is immediate. In a situation where the increase in demand is the quantity recycled and kept in store, additional cost is incurred, resulting in reduced additional profit.

In the long run, the industry might run at a loss if the additional cost $T_{\mathrm{sc}}$ equals the additional profit $\mathrm{X}_{\mathrm{o}}$. In order to keep the industry on alert, so as not to lose in the long run, the maximum profitable period, t, for keeping extra recycled quantities in storage is expressed in weeks. 
The proper application of this measure will always help the industry to make additional profit, even when extra quantities of products are recycled and kept in storage in order to meet unforeseen increases in demand.

In decision science, the use of the analytical hierarchy process (AHP) in prioritizing resources for recycling operations will bring immense benefits to researchers and practitioners. Other scholars could apply the newly-developed hybrid structural iteration matrix (HSIM) to the model presented in this work. The application of neurofuzzy modeling may stimulate long-lasting research, since new dimensions of recycling research would emerge.

An immediate follow-up study should be made of the sensitivity analysis and test of the model presented. The sensitivity should reflect the degree of responsiveness of model variables and parameters to changes in their values. Such an evaluation should reflect which of the model's parameter and variables are susceptible to changes, and which ones are the most sensitive.

Another area for further extension of the model is the development of optimized quantity for the model. A first instance may be the application of Lagrangian's multiplier to the existing model. Other optimization techniques may assist here too.

Furthermore, future extensions of the current model could incorporate some soft computing tools. A wide variety of such tools are available. Examples include fuzzy logic, genetic algorithm, artificial neural network, and neurofuzzy. Another dimension in improving the proposed financial model is the application of the concept of calculus. In particular, the calculus of several variables may be immediately applied. Further work could investigate modifying the model to form a continuous function. An investigation into case studies that show a comparative analysis might be interesting.

In conclusion, we have presented a financial calculation model capable of stimulating future research. We hope that the work serves as a guideline for new entrants.

\section{REFERENCES}

[1] Chen, K., 2001. Development of integrated design for disassembly and recycling in concurrent engineering, Journal of Integrated Manufacturing Systems, Vol. 12, No. 1, pp. 67-79.

[2] Craighill, Amelia L., Powell J.C., 1996. Lifecycle assessment and economic evaluation of recycling: A case study, Resource, Conservation \& Recycling, Vol. 17, No. 2, pp. 75-96.

[3] Cunningham, M.T., 1969, The application of product life cycles to corporate strategy: Some research findings, European Journal of Marketing, Vol. 3, No. 1, pp. 32-44.

[4] El-haram, M.A., Marenjak, S., Horner, M.W., 2002, Development of a generic framework for collecting whole life cost data for the building industry, Journal of Quality in Maintenance Engineering, Vol. 8, No. 2, pp. 144-151. 
[5] Fernandez, J.A.; De Oluveira, R. and Hochheim, N., 2002, Application of family life cycle concept in determining potential segment for housing projects: Case study of two down town projects in Florianopolis, Brazil, Vol. 20, No. 5, pp. 312-325.

[6] Gobin, K. and Mano, G., 2004, Polymer degradation to fuels over microporous catalysts as a tertiary plastic recycling method, Polymer Degradation and Stability, Vol. 83, Issue 2, pp. 267-279.

[7] Goosey, M. and Kellner, R., 2003, Recycling technologies for the treatment of end of life printed circuit boards (PCBs), Circuit World, Vol. 29, No. 3, pp. 33-37.

[8] Gronostajski, J. and Matuszak, A.A., The recycling of metals by plastic deformation: An example of recycling of aluminum and its alloys chips, Journal of Materials Processing Technology, Vol. 92-93, pp. 35-41.

[9] Helms, M.M. and Renfrow, T.W., 1994, Expansionary processes of the small business: A life cycle profile, Management Decision, Vol. 32, No. 9, pp. 43-45.

[10] Hutcheson, T.M., 1994, The life cycle economics of buildings, Facilities, Vol. 12, No. 5, pp. 11-15.

[11] Institute of Scrap Recycling Industries. http://www.isri.org

[12] Ishii, K., Eubanks, C.F.,, Di Marco, P., 1994. Design for product retirement and material life-cycle, Materials \& Design, Vol. 15, No. 4, pp. 225-233.

[13] Lawson, N., Douglas, I., Garvin, S., McGrath, C., Manning, D., and Vetterlein, J., 2001. Recycling construction and demolition wastes - a UK perspective, Journal of Environmental Management and Health, Vol. 12, No. 2, pp. 146-157.

[14] Lee, B.K.; Ellenbecker, M.J. and Moure-eraso, R., 2002, Analyses of the recycling potential of medical plastic wastes, Waste Management, Vol. 22, Issue 5, pp. 461-470.

[15] Larsen, B., 2001, The garbage life cycle model of quality management, The TQM Magazine, Vol. 13, No. 2, pp. 95-104.

[16] Lundquist, L,, 2000. Life cycle engineering of plastics: Technology, economy and the environment. Oxford; New York, Elsevier.

[17] Marsh, R.F., Meredith, J.R., and McCutcheon, D.M., 1997, The life cycle of manufacturing cells, International Journal of Operations and Production Management, Vol. 17, No. 12, pp. 1167-1182.

[18] Pohlen, T.L. and Farris, M.T., 1992. Reverse logistics in plastics recycling, International Journal of Physical Distribution and Logistics Management, Vol. 22, No. 7.

[19] Price, E.E. ad Donald, R.C., 2001, Life cycle management at 3M: a practical approach, Environmental Management and Health, Vol. 12, No. 3, pp. 254259.

[20] Recycling Today. http://www.recyclingtoday.com

[21] Recycling International. http://www.recyclinginternational.com

[22] Reed, R., 1987, Fashion life cycles and extension theory, European Journal of Marketing, Vol. 21, No. 3, pp. 52-62.

[23] Romualdo, R.M., Gelmires de Araujo, N., Heber, C.F. and Helio de Lucena, L., 2002. Recycling of granite industry waste from the northeast region of Brazil, Journal on Environmental Management and Health, Vol. 13, pp. 134-141. 
[24] Ross, S. and Evans, D., 2003, The environmental effect of rusting and recycling a plastic-based packaging system, Journal of Cleaner Production, Vol. 11, Issue 5, pp. 561-571.

[25] Smith, D.N., Harison, L.M. and Simmons, A.J., 1999, A survey of schemes in the United Kingdom collecting plastic bottles for recycling, Resources, Conservation and Recycling, Vol. 25, Issue 1, pp. 17-34.

[26] Tibben-Lembke, S.R., 2002, Life after death reverse logistics and the product life cycle, International Journal of Physical Distribution and Logistics Management, Vol. 32, No. 3, pp. 223-244.

[27] Treloar, G.J., Gupta, H., Love, P.E.D. and Nguyen, B., 2003. An analysis of factors influencing waste minimization and use of recycled materials for the construction of residential buildings, International Journal of Management of Environmental Quality, Vol. 14, No. 1, pp. 134-145.

[28] Zineldin, M., 1996, Bank-corporate client partnership relationship: Benefits and life cycle, The International Journal of Banking Marketing, Vol. 14, No. 3, pp. 14-22.

\section{ACKNOWLEDGEMENT}

The authors gratefully acknowledge the contributions of the anonymous referees whose comments improved the paper a great deal. 